\title{
Music as a Resource for Drawing Symbolic Boundaries within the Turkish Diaspora in Germany
}

\section{Ali Türünz}

\begin{abstract}
The paper presents the findings of an ethnographic study of five Turkish music choirs from Hamburg from the perspective of cultural sociology, focused on the meaning-making process. Following Andy Bennett, music is regarded as a resource, and then it is scrutinized how Turkish immigrants make sense of their lives through music. The research is based on the qualitative analysis of indepth, semi-structured interviews with choir members from Hamburg. The paper elaborates on how choir members use music as a resource to draw internal symbolic boundaries within the Turkish community. Participants draw symbolic boundaries against the majority of the Turkish population living in Germany. On the basis of the distinction they make between refined music and the uncultured music exemplified, choir members deliberately create a number of sacred and profane binaries in the Durkheimian sense.
\end{abstract}

KEY WORDS Turks in Germany, Turkish music, migration, symbolic boundaries, arabesk

\section{Introduction}

This article is about three Turkish folk choirs (the ATU, the Serdar Kalan Choir, and From Soul to Soul) and two classical Turkish music choirs (the Osman Sadık Choir and the Lale Hoşses Choir) in Hamburg. Its overall aim is to explore the role of music in the Turkish migration context in Germany. More specifically, it is a micro-level, in-depth, ethnographic study of five Turkish music choirs from Hamburg. The choir members use music as a resource to draw internal symbolic boundaries within the Turkish community. The participants draw symbolic boundaries against the majority of the Turkish population living in Germany, primarily the listeners of the Arabesk music genre. On the basis of a distinction they make between refined music (Classical, Art, Folk, and Western Classical music) and the uncultured music exemplified by Arabesk, the participants in this research project deliberately create a number of sacred and profane binaries in the Durkheimian sense. According to Alexander (2003: 186), "Whereas the sacred provides an image of the good with which social actors seek community and strive to protect, the profane defines an image of evil from which human beings must be saved".

Sociální studia / Social Studies 4/2016. Pp. 81-96. ISSN 1214-813X. 
Binaries between refined and uncultured genres are not confined to the realm of music, but expand to the lifestyles connoted by the genres. In short, the research participants present themselves as secular, educated citizens, well integrated into German society, who are associated with the culture of large cities, primarily Istanbul, and urban values, as opposed to Turks of rural origin, associated with the culture of Anatolia, whose behaviour is bigoted, uncultured, and impure, and hence, they lack the capacity to integrate in Germany. The research participants despise Arabesk listeners even if they are rich, due to the perceived cultural inferiority and the value that they put not on money and wealth, but on professional success and having an influential circle of friends. Furthermore, for the participants it is highly undesirable to be lumped together with all the other Turks in Germany. Thus, the highly fragile position of Turkish immigrants in Germany necessitates rejecting Arabesk music due to the stigma attached to it and its association with rural-urban migrants in Turkey.

\section{Methodology}

The research is based on a qualitative analysis of more than 50 in-depth, semi-structured interviews with choir members from Hamburg, and an additional 15 interviews with musicians and music instructors of Turkish origin from Berlin, Mannheim, and Vienna, conducted between 2009 and 2012. I initiated the field research as a part of my $\mathrm{PhD}$ project in October 2009 during my five month stay as an Erasmus student at the University of Hamburg. Later on, I spent an additional four weeks in Hamburg in 2012 to deepen my knowledge of the field. Also, I spent one month in Berlin in 2010 and visited Vienna several times from 2009 to 2012. In addition, during my two weeks of library research in Frankfurt I conducted a short research in nearby Mannheim.

As a cultural sociologist focused on the "meaning-making" (Spillman 2002: 1) process, I found participant observation and in-depth interviews relevant to my research. The reason is that the data gathered in this way allow for "the analysis of data involves interpretation of the meanings, functions, and consequences of human actions and institutional practices, and how these are implicated in local, and perhaps also wider, contexts" (Hammersley and Atkinson 2007: 3).

Inspired by the documentary method, my questions ask "how" rather than "what". The documentary method is related to Mannheim's sociology of knowledge (Bohnsack and Nohl 2003: 371). To grasp "documentary meaning", the researcher should inquire "how: how is practice produced or accomplished" (Ibid.). That is to say, the researcher should seek "the modus operandi of practical action" (Ibid.). The documentary method is able to deal with the "aporie between subjectivism and objectivism" by "the change from the question what reality is in the perspective of the actors, to the question how this reality is produced or accomplished in these actors' everyday practice" (Bohnsack et al. 2010: 101-102).

My analysis and writing process utilized "thick description". The interviews were semi-structured and conducted in the form of friendly conversation (e.g. "Tell me, how did you start playing music?"), so as to encourage the participants to talk freely and at length. It allowed for detailed and rich elaboration. For Geertz, the aim of thick description is "to 
draw large conclusions from small, but very densely textured facts; to support broad assertions about the role of culture in the construction of collective life by engaging them exactly with complex specifics" (Geertz 1973: 28). As Alexander points out, Geertz's “thick description of the codes, narratives and symbols that create the textured webs of social meaning" (Alexander and Smith 2003: 13) should guide the researcher. Furthermore, according to Alexander, this is "a first step in the construction of a strong program in the hermeneutic project of 'thick description' itself' (Alexander and Smith 2003: 22).

Additionally, for analysis of the interviews, I used the qualitative analysis software Atlas.ti. First, I conducted line-by-line coding, which was followed by focused and theoretical coding. Focused coding "means using the most significant and/or frequent earlier codes to sift through large amounts of data" (Charmaz 2006: 57), whereas theoretical codes "specify possible relationships between categories you have developed in your focused coding" (Charmaz 2006: 63).

The codes emerged from the similar answers I received during the interviews. The most common codes were "Arabesk and disgust"; "Criticizing other Turks"; "Diversity of Turks in Germany"; "Discrimination and racism in Germany"; "Prejudices against Turks"; "Stigmatization"; "Feeling equal to Germans"; "Turkish-German binary"; "Advantages of Germany"; "Having or not German friends"; "Singing and happiness"; "Singing and stress relief"; "Unifying effect of music".

To summarize, the research is based on participant observation and in-depth interviews, allowing detailed "thick description" based on the assumption that the views of actors are crucial for the understanding of phenomena. Finally, it is important to underline that this study does not represent a study on German-Turks in general. It is a qualitative study of a particular milieu.

\section{Theoretical framework}

I approach the study of Turkish choirs in Hamburg from the perspective of cultural sociology. My work is based on the premises of the strong program in cultural sociology, initially developed by Alexander and Smith (2003).

To begin, Alexander and Smith draw the lines of demarcation between "cultural sociology" and "sociology of culture". In the former, culture is an "independent variable" that possesses relative analytical autonomy, whereas in the latter, it is a "dependent variable" (Alexander and Smith 2003: 12). The authors criticize the Marxist understanding of culture for reducing culture to the superstructure and, consequently, to something determined by the "base" (Alexander 1990: 2-3). By proposing that the sociology of culture seeks to assign culture space out of "the domain of meaning", they implicitly suggest that meaning is important to cultural sociologists (Ibid.).

Lyn Spillman also confirms the centrality of "meaning-making" to cultural sociology (Spillman 2002: 1). The discourse of some ethnographic works that follow a constructivist approach intersects with cultural sociology in that both methodologies seek to avoid a reductionist view of culture; "meaning and interpretation are active and fluid processes" (Spillman 2002: 4). Spillman's main dissatisfaction with ethnographic writing lies in the fact 
that it only focuses on the "deviant and powerless" and somehow ignores "mainstream culture" (Ibid.: 6). What seems plausible for ethnography studies is to accept the "autonomy of culture" and to seek to "discover the nature of internal and subjective structures", as discussed by Alexander in his account of "hermeneutics" (Alexander 1990: 3).

Furthermore, my research takes music as a resource in Bennett's sense. Bennett suggests that the most important gift of sociology of music following the cultural turn has been its perception of "music as a resource" (Bennett 2015: 143). The author concludes: "Music serves as a cultural resource in the formulation and articulation of individual and collective identities" (Ibid.: 150). Bennett summarizes what music can indicate: "national identity"; "a symbol of taste"; "an alternative lifestyle". He adds that music is also researched in the frame of "locality", "memory", "body", and "technology" (Bennett 2015: 143). Bennett argues that music "plays a key part in the formation and articulation of identity", and it "can become a strong marker of national identity, for example, in the form of national anthems and similar pieces of music or songs with a strong patriotic flavor" (Ibid.: 143). He is of the opinion that "music and national identity become interwoven in highly complex ways" (Ibid.: 144). Drawing from Stokes (1994: 3), he affirms that music "plays a critical function in informing 'our sense of place"” (Bennett 2015: 133).

In addition, for the analysis of the choirs, I use the concept of symbolic boundaries, proposed by Lamont (1992). In short, symbolic boundaries are "the types of lines that individuals draw when they categorize people - and high-status" (Lamont 1992: 1). Lamont suggests that there are three types of symbolic boundaries: moral, cultural, and socioeconomic. Although Lamont's work partly draws on that of Pierre Bourdieu, she criticizes his insistence on the significance of cultural and socioeconomic boundaries.

Unlike Bourdieu, Lamont considers moral boundaries "drawn on the basis of moral character, they are centered around such qualities as honesty, work ethic, personal integrity, and consideration for others" (Lamont: 1992: 5), as crucial to making distinctions. In my research, in some cases, moral boundaries between Alevis and Sunni Muslims are apparent in the discourse in the interviews of the research participants. More significant are the cultural boundaries and moral boundaries (Lamont 1992) drawn against many Turks and Kurds living in Germany.

Lamont writes: "Cultural boundaries are drawn on the basis of education, intelligence, manners, tastes, and command of high culture. Someone who describes all of his friends as refined is drawing cultural boundaries" (Lamont 1992: 4). What is evident is that when the participants in my research create distinctions from other Turks in their narratives about taste, they employ cultural boundaries. Music is a cultural resource that allows the participants to deliberately position themselves as culturally superior. However, it is noticeable from the accounts that in the case of ethnic Germans, cultural boundaries play a much less prominent role even though they are sometimes evident. Music is not a cultural resource that sets strict boundaries between the participants and ethnic Germans. What is more prominent in drawing boundaries against ethnic Germans is that participants construct moral boundaries in relation to what they perceive as the differences between Turkish and German qualities. It is not a distinction between sacred and profane, but a distinction between sacred 
and differently sacred. In the choirs, German music is not othered. German classical music is respected, and German pop is not a symbol of otherness.

Socioeconomic boundaries, for Lamont, "are drawn on the basis of judgments concerning people's social position as indicated by their wealth, power, or professional success" (Lamont 1992: 4). I have certain reservations about using Lamont's definition literally, because in the Turkish migratory case, wealth only is despised. However, "professional success" or having a circle full of "very influential among the local elite" is highly respected and desired.

Lamont's critique of Bourdieu's approach that "worldviews are primarily defined by habitus ${ }^{1}$ (via proximate environmental factors)" (Lamont 1992: 181) is very appropriate while evaluating the Turkish case. Lamont states that her study demonstrates "the importance of considering the roles of macrostructural determinants and cultural repertoires in shaping tastes and preferences" (Lamont 1992: 181). To summarize, from the perspective of cultural sociology, in this article I consider music to be a resource for internal differentiation within the Turkish diaspora that takes the form of drawing symbolic boundaries.

\section{Five Turkish music choirs in Hamburg}

The main part of the field research took place in Turkish music choirs - three folk (the ATU, the Serdar Kalan Choir, and From Soul to Soul) and two classical (the Osman Sadik Choir and The Lale Hoşses Choir). The following table represents an overview of all five choirs regarding repertoire, leadership, membership, articulated goal, reasons for joining the choir, and political position:

In essence, all of the observed choirs are secularist. Their members openly voice resentment against the islamization of Turkey by the current party in power, the AKP (Justice and Development Party). Hence, it is not a coincidence that there are no veiled female participants in any of these five choirs. Participants argue that the primary aim of assembling in a choir is to perform Turkish music altogether. As the number of people interested in joining Turkish music choirs is limited in Hamburg, the participants tend to put forward their mutual interests, rather than placing emphasis on their minor differences.

Despite the divergences between and within these choirs, none of them includes migrants lacking knowledge of the German language. Parallel to the general view of Turkish music, the folk choirs tend to have participants reflecting rural values in Turkey, whereas the classical music choirs tend to have those who reflect the urban values of Istanbul.

All choirs were comprised of mixed males and females from different generations. Most of the members, though, were middle-aged and held skilled factory and service sector jobs with the exception of some teachers, translators, and university students. Ethnic, religious, and political identities were (mostly) not allowed to be in the foreground. Except for one German-Turkish student of the bağlama, all of the participants were German Turks.

"The habitus is a necessity internalized and converted into a disposition that generates meaningful practices and meaning-giving perceptions" (Bourdieu 2010: 166). 
Table 1: Overview of Turkish music choirs in Hamburg

\begin{tabular}{|c|c|c|c|c|c|}
\hline & The ATU & $\begin{array}{l}\text { The Serdar Kalan } \\
\text { Choir }\end{array}$ & From Soul to Soul & \begin{tabular}{|l} 
The Lale \\
Hoşses Choir
\end{tabular} & $\begin{array}{l}\text { The Osman } \\
\text { Sadık Choir }\end{array}$ \\
\hline Repertoire & Turkish Folk & Turkish Folk & Turkish Folk & Turkish Art & $\begin{array}{l}\text { Turkish Art, } \\
\text { Turkish } \\
\text { Classical, } \\
\text { Turkish } \\
\text { Avant-garde }\end{array}$ \\
\hline Leader & Teacher & $\begin{array}{l}\text { Bağlama player } \\
\text { (music ian) }\end{array}$ & $\begin{array}{l}\text { School teacher } \\
\text { in Turkey, cleaner } \\
\text { in Gemany }\end{array}$ & $\begin{array}{l}\text { Professional } \\
\text { singer from } \\
\text { the state radio }\end{array}$ & $\begin{array}{l}\text { Retired } \\
\text { computer } \\
\text { programmer }\end{array}$ \\
\hline Membership & $\begin{array}{l}\text { Nearly } 30 \text { mem- } \\
\text { bers; Secular; } \\
\text { Mostly above } \\
30 \text { years; Ha- } \\
\text { ving urban } \\
\text { values, but } \\
\text { a considerable } \\
\text { number of par- } \\
\text { tic ipants a re } \\
\text { of rural origin. }\end{array}$ & $\begin{array}{l}\text { Nearly } \\
20 \text { members; } \\
\text { Predomina ntly } \\
\text { aged under } \\
\text { 30; Mostly rural } \\
\text { origin; Not overtly } \\
\text { religious; Ranging } \\
\text { from university } \\
\text { students to semi- } \\
\text { professional. }\end{array}$ & $\begin{array}{l}\text { Nearly } \\
20 \text { members; } \\
\text { Predominantly } \\
\text { comprised } \\
\text { of people over } \\
40 \text { years and } \\
\text { the retired; } \\
\text { Mostly rural; } \\
\text { Inc ludes nurses, } \\
\text { technicians, } \\
\text { cooks, etc. }\end{array}$ & $\begin{array}{l}\text { Nearly } \\
25 \text { members; } \\
\text { Mostly above } \\
40 \text { years and } \\
\text { includes many } \\
\text { retired people; } \\
\text { Predominantly } \\
\text { urban; } \\
\text { Secular. }\end{array}$ & $\begin{array}{l}\text { Nearly } \\
20 \text { members; } \\
\text { Mostly a bove } \\
30 \text { years; } \\
\text { Overtly secular } \\
\text { and mostly } \\
\text { urban-origin; } \\
\text { Includes } \\
\text { Alevis and } \\
\text { dissidents }\end{array}$ \\
\hline Articulated goal & $\begin{array}{l}\text { "Transmitting } \\
\text { Turkish music } \\
\text { in Germany } \\
\text { to the Turkish } \\
\text { people." }\end{array}$ & $\begin{array}{l}\text { "Introducing and } \\
\text { spreading Turkish } \\
\text { culture, music, } \\
\text { and folklore } \\
\text { in Germany." }\end{array}$ & $\begin{array}{l}\text { "Reviving Turkish } \\
\text { Folk music } \\
\text { in Gemany and } \\
\text { rescuing it from } \\
\text { the degenerative } \\
\text { influence } \\
\text { of Arabesk." }\end{array}$ & \begin{tabular}{|l|} 
"Transmitting \\
Turkish music \\
to the younger \\
generations."
\end{tabular} & $\begin{array}{l}\text { "Performing } \\
\text { the canons } \\
\text { of Classical } \\
\text { Turkish Music } \\
\text { rather than } \\
\text { very popular } \\
\text { songs." }\end{array}$ \\
\hline $\begin{array}{l}\text { The reasons for } \\
\text { joining the choir }\end{array}$ & \begin{tabular}{|l|} 
"People \\
have to live \\
in a soc iety." \\
"Choir \\
members come \\
here and relax \\
after working \\
for 40 hours per \\
week."
\end{tabular} & $\begin{array}{l}\text { "Actually, people } \\
\text { first come into } \\
\text { the choir just to } \\
\text { see their friends, } \\
\text { but then we start } \\
\text { singing folk songs } \\
\text { together." }\end{array}$ & $\begin{array}{l}\text { "We are like } \\
\text { a family here." } \\
\text { "I feel confident } \\
\text { and relaxed } \\
\text { here." }\end{array}$ & $\begin{array}{l}\text { "Turkish music } \\
\text { hasa thera- } \\
\text { peutic effect. } \\
\text { People are } \\
\text { engaging } \\
\text { in therapy } \\
\text { here." }\end{array}$ & $\begin{array}{l}\text { "I release my } \\
\text { daily stress } \\
\text { by singing. } \\
\text { The wories } \\
\text { related to work } \\
\text { and all the sad } \\
\text { stuff just } \\
\text { disappear." }\end{array}$ \\
\hline $\begin{array}{l}\text { Political } \\
\text { position (in order } \\
\text { of prevalence) }\end{array}$ & $\begin{array}{l}\text { Secula rist; } \\
\text { na tiona list }\end{array}$ & $\begin{array}{l}\text { Secula rist; } \\
\text { nationa list; } \\
\text { moderate } \\
\text { Isla mists (minonity) }\end{array}$ & $\begin{array}{l}\text { Secula rist; } \\
\text { na tiona list; } \\
\text { a politic al }\end{array}$ & $\begin{array}{l}\text { Apolitic al; } \\
\text { sec ula rist; } \\
\text { nationa list }\end{array}$ & $\begin{array}{l}\text { Secula rist; } \\
\text { Kurdish } \\
\text { liberta rian; } \\
\text { left-liberal }\end{array}$ \\
\hline
\end{tabular}

Source: Author

\section{Sacred and profane in the Turkish diaspora: drawing symbolic boundaries}

Arabesk music has been a symbol of cultural division within Turkish society since its emergence following large-scale migration from rural areas to large cities in Turkey. Along with "Arabesk music", words such as "Arabesk novel", "Arabesk film", “Arabesk democracy", and "Arabesk economy" are used in a pejorative sense to underline the "degeneration" of Turkish culture and society (Özbek 1991: 22). Hence, the Arabesk is not confined to the realm of music, but in a broad sense refers to a "culture of the ruralrooted population who could not participate in urban life". In this view, those rural people stuck "between tradition and modernity" cling to their traditions, but at the same time 
strive to adopt the city life. Thus, Arabesk is taken by many Turkish scholars as the cultural entity of a "transitional society". The scholars defending this view also suggest that it is a "deteriorated" form of the traditional, but at the same time a non-modern "marginality". Furthermore, as Öncü summarizes:

The epithet Arabesk denotes impurity, hybridity, and bricolage and designates a special kind of kitsch. The word was first coined in the late 1960s and early 1970s to describe a hybrid music genre that emerged and acquired immense popularity among recent immigrant populations of Istanbul (Özbek 1991; Stokes 1992; Markoff 1994). Banned from state radio and television for defying established canons of both folk and classical Turkish music, by intermixing rhythms and instruments from popular Western and Egyptian music, Arabesk music soared in the expanding cassette market of the 1970s. (Öncü 1999: 104)

According to Martin Stokes, Arabesk in Turkey has been associated with the genre of the "labour migrants from the south-east of the country, a backward and exotic orient existing as a revealing anomaly in a Westernized and secular state" (Stokes 1992: 8). It is considered "the domain of morbid emotion and sensitivity (duygu), a domain entirely separable from 'culture' (kultur)" (Stokes 1992: 11). Furthermore, it "represents a world of decay and despair, in which signifiers of disorder are linked directly to signifiers of a subversive, internal Orient" (Stokes 2000: 216). As the author reminds us, this genre is associated with the cliché that Arabesk was "fatalistic and masochistic, encouraging a passivity that had no place in a modernizing republic" (Stokes 2010: 100).

For another ethnomusicologist, Uğur Küçükkaplan, the Arabesk genre has developed from the commercialized styles of Turkish Classical music and Turkish Folk music (Küçükkaplan 2013: 137). For Küçükkaplan, Arabesk is debated in the Turkish public nowadays not simply as a music genre, but in terms of being a symbol of political and cultural problems (Ibid: 293).

In public debates, on TV shows, and among the mainstream media in Turkey, Arabesk is widely regarded as a genre for migrants who hailed from villages and settled in large cities. The members of the choirs are well-informed about these discussions. The fact that participants use some of the arguments that the Turkish intelligentsia have used about Arabesk suggests that they have read or heard about these arguments, for example, the "disharmony of Arabesk". In many ways, the participants are influenced by, using Bauman's (1987) term, the "legislators" around them and their thoughts are shaped by this influence. According to Bauman, the legislator's role "consists of making authoritative statements which arbitrate in controversies of opinions and which select those opinions which, having been selected, become correct and binding" (Bauman 1987: 4).

The moral meanings assigned to Arabesk represent overwhelmingly the reasons why choir participants express strong dislike towards it. The moral reasoning is complex, as it is also concerned with the status of the choir members in Germany. As most of the participants I interviewed express, in having been othered and not totally accepted by the majority society, they can be compared to the Turkish/Kurdish labour migrants who settle in Istanbul and are othered by Istanbulites. Yet, most of the choir members adopt the tone of "non-migrant" Istanbulites who perceive themselves as elites in society. Hence, 
the internal dichotomy created by the "culturally superior" Turks in Germany replicates the negative attitudes and disdain of Istanbul elites towards their economically and socially deprived co-citizens.

The highly sensational column written for Radikal Daily by Turkish writer and columnist Mine Kırikkanat, who has lived in France and has therefore experienced what is to be a migrant, is the paradigmatic expression of the aversion of Istanbulite elites to internal rural migrants. The following extract fully reveals White-Turks' stereotypes about Black Turks:

\begin{abstract}
After the Ataturk Airport... Alongside the sea begin the territories of - not even Arabia - but a version of Ethiopia... or we may as well call it, the "Carnivore Islamistan". Anything non-Istanbul, anyone not from Istanbul is here. Three million people... move to Istanbul (every year) to graze on meat on the grass on Sundays... As cars pass by the green space... the only thing that is at eye level is the barbecue grills. Men in their undergarments lie down and chew like cows, women either wearing black chadors or a headscarf - but covered without exception - fan the grill, prepare tea and cradle their babies or push them on the swing... Our inlander people turn their behinds to the sea, grill, and eat meat with no exception. You can never see a single family among them who cook fish! Perhaps, if they liked fish, if they knew how to cook fish, they would not lie down with their dirty white tank tops and long underwear, perhaps they would not scratch themselves continuously, would not chew like cows, would not be so thick, so short-legged, so long-armed, and so hairy. (Kirıkkanat 2005 cited in Demiralp 2012: 516)
\end{abstract}

Certainly, the lines above represent the most extreme form of disdain for migrant labourers in Istanbul. The author emphasizes an absolute absence of anything in common between herself and other representatives of Istanbul, with its culture and lifestyles, and on the other hand "everything non-Istanbul". The categorical differences come in the form of physical appearance, dietary habits, etiquette, dress code, and perhaps the Weltanschaung (inlanders who turn their backs to the sea). Fundamentally, secular Istanbul is invaded and polluted by the provincial "Islamistan".

Accordingly, most participants in my research project see themselves as ideal and modern citizens (having Turkish or German passports, or both), who are well oriented in Germany, but embrace "Turkish culture", which is surely a much contested term even among Turkish immigrants. Those who come from Istanbul, Ankara, or Izmir tend to distinguish themselves from the "inferior" migrant labours, who have come to Germany and "never changed". The more educated the participant is, the harder it is to accept that he or she is an "ordinary" Turk living in Hamburg.

Aziz (56, ATU), a school teacher, underlined the appeal of Western Classical music for him and claimed that he could not find himself in the Arabesk genre when answering the question "Do you go to the concerts of any famous musicians from Turkey who come to perform in Germany?"

Sure, I never miss the concerts of Faz1l Say [a Classical music pianist]. Then, there are Pekinel Sisters [Classical music pianists]; I also don't miss their concerts and listen to them with great pleasure. Fazil Say came, but did I go to his concerts consciously? First of all, I went there because an artist from Turkey came to perform. Then I listened to him. I had great pleasure. 
In other words, I noticed that mostly this kind of music appealed to my soul in the process. For example, İbrahim Tatlıses [a famous Arabesk singer] does not give me that much pleasure. $\mathrm{He}$ might certainly be a good musician in his genre. However, when I listen to the Pekinel sisters, I see much more of myself in their music; I see a lot of myself when I listen to Fazll Say.

The speaker above represents a good example of the model citizen of the early Turkish Republic, which embodied a transformational project, and the idea of the state was to educate people about high art, such as Western Classical music. His professional role as a teacher required him to absorb the transformational role of the Republic. From the establishment of the Turkish Republic, teachers have been crucial carriers of official state ideologies and transmitters of officially accepted and propagated cultural forms. According to Demiralp, "The Turkish education system defines the meaning of being Turkish and how to be a responsible citizen. It designates ideas, ideologies and lifestyles that remain outside this model as wrong, inferior or treason" (Demiralp 2012: 518). In particular, participants with a professional background in teaching emphasized the need and the responsibility to cultivate and develop the musical tastes of youngsters. Aziz apparently internalized the division between legitimate high culture (Western Classical music) and vernacular forms such as Arabesk. Although he admits that Tatlises may be a "good musician", his soul cannot find pleasure in listening to that kind of song.

During the rehearsal of the From Soul to Soul choir, the only female instrumentalist, Sevim (51), expressed her disapproval of the lyrics of a song they were singing. She stated: "What people like is not always right. This song is about the marriage of a 15-year-old girl, and we are, of course, against such a thing, so we are changing the words". She complained that some songs in Turkish Folk music have "primitive" lyrics, such as, in her words, "I am dying; I am burning, come to my grave, cover your head with the headscarf and all that nonsense". For her, there is a pressing need to compose didactic folk songs for the people, which evokes a discourse that intellectuals should enlighten and educate the masses.

Another participant, Sinan (47, ATU), expressed more explicitly his aversion toward Arabesk. For him, Arabesk means disharmony, albeit its instrumentalization can be excellent. Nonetheless, in Sinan's opinion, the lyrics are typically disharmonious and disappointing when fused with the music. When I asked him who listened to Arabesk, he went back to the initial years of Turkish immigration to Germany:

Arabesk is terribly disturbing to my brain. Its lyrics are, as well. Although I perform music as a hobby, I do not claim to be a musician. We were here in Germany in the 70 s when nobody was here. Back then, there was a friend who was playing the saz perfectly. He was giving saz lessons, and the guys who were attending his classes generally liked Arabesk music. Those young guys who were coming to these classes were mostly from central Anatolia or eastern Anatolia. They were coming from the lower classes. I did these two evaluations. I was frequently thinking about it, I mean I came from Turkey, but from Istanbul. I know neither these people nor their culture; they seemed to me to have an entirely different culture. Their colours and tastes seemed to me very different from mine. I said to myself that I was probably at the wrong place. The majority was like that at that time. Most of them had a tendency toward Arabesk. I could not get used to it somehow. 
Being one of the early comers, Sinan reports that he had met Turkish people entirely alien to him. His account closely resembles the aforementioned statement by Kirikkanat, when remembering his 40-year-old memories, as he underlines his inability to get used to the majority. By mentioning "colours", Sinan refers to the skin colour of the people with whom he was comparing himself. He categorically regards himself, as a person from the Turkish cultural capital, as different from the lower classes of conservative and religious Central and Eastern Anatolia. Two sides of Turkey, each personified in its own physiognomy and culture, come to know each other in the migratory context. Sinan's, as well as Kirıkkanat's, account belongs to what Demiralp labels as urban secularist discourse. As Demiralp puts it:

The portrayal of Islamic individuals as provincial, lower class actors is not only an outcome of the overlapping of socioeconomic, geographic and cultural cleavages. This depiction of Islamism is also a product of the urban secularist discourse, which has actively attributed religious, cultural, and even physical characteristics to Anatolian populations, in order to define its own (secularist, civilized and Westernized) identity and to justify its authority. (Demiralp 2012: 512)

This discourse has apparently persisted over the decades and has not significantly diminished in the diaspora. The narratives of the participants reveal their frustration when being "mistaken" for such Turks by ethnic Germans.

Additionally, the participants react against the perceived "Arabesk" representation of Turks evident in the movies of acclaimed Turkish-German director Fatih Akın. Akın's film, Head-On (Gegen Die Wand), is associated with the tradition of Arabesk films in Turkey (Berghahn 2011: 249). The author draws from Zaimoğlu and suggests that the film's main characters' cutting themselves with sharp razors is reminiscent of fans cutting their bodies at pop concerts to express "ecstasy and agony" (Ibid.: 249). Actually, the cutting ritual at concerts is widely associated with the Arabesk performances of the singer Müslüm Gürses in Turkey. Jale (26, Serdar Kalan), a graduate of the Faculty of Social Sciences in Hamburg, comments:

\footnotetext{
Well, Germans say in a caricaturing manner to each other, "You know there is a film about the lives of Turks, Gegen die Wand [Head-on]; it is really cool!" They think as if it was the only cultural source about Turks. Ok, it is just a single example. But, are all the Turkish women having the conflicts of the main female character, Sibel, in the film? Germans think so. It is certainly a good and important thing that Fatih Akın has become a good film director. However, there is a widespread perception among Germans now that there is only Fatih Akın, who is involved in films and the arts in general among Turks. They do not know anyone else.
}

Jale, along with many other participants, rejects the stereotype of one true Turkish way of life and the practices and values related to it. This case demonstrates that the disdainful attitude toward Arabesk is not limited only to musical taste itself. It is, as Öncü states, against "the cultural habitus and lifestyle of those who enjoyed them. Arabesque lovers now belonged to 'Arabesk culture' - banal, trashy, but most of all, in-between, hence polluted and polluting, to invoke Mary Douglas (1966)" (Öncü 1999: 104-105). Hence, what happens first, is that those who feel the stigma in the choirs ward off the stigma that comes from the majority society in Germany by suggesting "We are not them". Secondly, they show who should actually be the target of the stigma: the despicable Arabesk mass. 
Alexander and Bartmanski state "the sensuous surface effects of contemporary icons actually range much more widely, to popular songs" (Alexander and Bartmanski 2012: 2). In this case, our focus is on a genre, Arabesk, which has transformed into an icon of "invasion" (Öncü 2002) and "pollution" (Douglas 1966; Öncü 2002). In order to comprehend "iconic consciousness", Alexander proposes that "aesthetic and moral approaches", in other words, "surface" and "depth", should be blended (Alexander 2012: 26). As often stated by the choir participants, Arabesk aesthetically (in terms of vocals and sound) appears disturbing and disharmonious to them. It is described to have unsophisticated lyrics and sound compared to Turkish Folk and Art Music. Since Arabesk is influenced highly by Arabic-Egyptian music, it is not national, according to some choir members. The fact that it has connotations from the Arabic world makes it sound uncool for some of the interviewees.

Dismissing Arabesk and its association with Arabic culture, while simultaneously aspiring to revitalize the culture of Istanbul, even though one does not have roots in the city, is a common denominator of the Turkish classical choir. "The wandering melancholic as lover citizen" is the term Stokes uses to describe the song "Aziz Istanbul" (Stokes 2010: 5). Melancholy could be named as the particular emotion that participants seek in music. They express longing for an imaginary homeland from a distance with slow and melancholic songs. The Osman Sadık and the Lale Hoşses Classical Turkish choirs have a tacit goal to revive an "imagined" culture of "old" Istanbul. For most of the members of the choirs, cherishing their culture is of utmost importance. However, this culture is not the culture of the entirety of Turkey, but rather the elite culture of Istanbul. Even those people born in other Turkish cities associate themselves exclusively with Istanbul. They express nostalgia for "old" Istanbul, which presumably existed when it was significantly smaller and culturally homogeneous, before its population rose to nearly 15 million. The following account of Cemalettin (28), a violin instructor from Mannheim, reveals the yearning to revive an imaginary Istanbul and argues that an impediment to doing so is the Turkish population itself living in the city.

Cemalettin: Actually, I have a dream, but to open a typical Turkish meyhane [tavern]. An old, vintage place from the 1920 s or 1930 s. It is not necessary to invest a lot. Just a gramophone at the corner, perhaps an ensemble. A daily menu. Some side dishes, a few drinks, that's it. I'm not asking too much. But, you cannot do it here.

Researcher: Because you do not accept everyone?

Cemaletin: No, it is not like that.

Researcher: Islamists?

Cemalettin: Islamists would not be interested in visiting our place; we are kind of comfortable in that respect. Rather than not accepting everyone, what I am thinking is to introduce an alcohol limit. You see that someone is drinking, after the third glass, and when you spot aggressive behaviour, you will say, "We are sorry, that's it for today". And to say "our drinks are over". But, in order to accomplish what I say, you need to have a drinking etiquette. You can do it in Istanbul or Izmir. But, there is no such drinking etiquette here. Unfortunately! Most of the people here have not gone through this education. Is it a bad thing? Perhaps it is not but as such, uneducated people are in the majority, you cannot open such a place. The customer would say, "What is this, 
my brother? Why don't you play some Arabesk?" when he gets in and hears "Aziz Istanbul" [a canonical Art music song from Münir Nurettin Selçuk]. That's why, you cannot do it here and you would lose all your financial sources until you achieve your goal.

As the interview demonstrates, the participant has a low opinion of Mannheim's Turkish immigrant population. His reasoning stems from the fact that the Turkish immigrants in Mannheim lack appropriate manners, which for him exist among Istanbulites or residents of Izmir. He has an imagined vision of Istanbul, the Beyoğlu (Taksim) districts from the 1960s and 1970s. He is disturbed by the fact that Turkish people without manners inhabit Mannheim. Although he does not use the term maganda, he refers to a particular type of person who often creates a scene in public. In the 1990s, a new derogatory term maganda was coined. First, it was used in satirical magazines, but quickly it became a widely used word to refer to "a figure of brute strength, hairy body, and unbridled sexual appetites, who infects and pollutes the cultural atmosphere of social settings he appears in" (Öncü 1999: 111).

The participants tend to presume that those Turks who are not like them will not have the intent to join their choir. When I asked Bora (26, Lale Hoşses), a musician, musicologist and translator born in Germany, what he observed as criteria to be accepted as a participant in the Lale Hoşses choir, such as sharing the same mainstream secularist political view of the choir, he responded with a giggle: "Well, it is not a criterion, but this is rather in the unconscious. Because, it is taken for granted in the minds of people, they cannot even think that what they believe can even be politically criticized. For them, it would be unthinkable to have some participants who are against their political views".

I have not observed that the majority of Turkish music performers set strict economic boundaries against many other Turks or Kurds in Germany or Turkey. Socioeconomic boundaries, for Lamont, "are drawn on the basis of judgments concerning people's social position as indicated by their wealth, power, or professional success" (Lamont 1992: 4). Here, using Lamont's definition literally is problematic, because in the Turkish migratory case wealth only is despised. However, "professional success" or having a circle full of the "very influential of the local elite" is highly respected and desired. The participants often use terms such as alt tabaka (low layer/low class). However, this term connotes low cultural and moral standards rather than economic status.

The participants despise individuals whose material achievements are not coupled with educational level and cultural refinement. Osman Sadık contrasts Turkish and German society in regard to showing one's wealth and the significance it has:

Money talks in Turkey. Whoever has money talks there. And unfortunately, that man is someone who cannot formulate a proper sentence. Actually, he is not valuable in our eyes. But, he says, "I am a hillbilly [kıro] but I have money". Unfortunately, there are so many status symbols in Turkey; you can see them when you also look at the cars. Hamburg is a city that hosts most of the millionaires in Europe and in the world. Nevertheless, you don't see their bodyguards walking around with them when they show up in the city centre. It is not a place where paparazzi walk with them unlike in Turkey. He/she shops just like you and me in a plain manner. 
According to Stokes, "The terms maganda, kıro, and sometimes kabadayl are used today by critics to describe this "arabesk-type" (Stokes 2000: 223), and the choir participants avoid being associated with such people. On the contrary, participants commonly enjoy being associated with and surrounded by the intellectual class. I asked Erkan, the owner of a music school in Vienna, what the Turkish [Türkiyeli] intellectual milieu was and where intellectuals were "hanging out". He replied with a rather proud tone:

For instance, we have friends who are painters, and they are seriously dedicated to their art. Some of our friends are lecturers in academia; then we have musician friends, sociologist friends, and friends who are scientists. They attend elite and exceptional events. For example, they join in the activities that we organize. They have a high opinion about Tim because of the job we are doing and because of our perspective. These people are interested in multicultural activities. Austrians target the intellectual audience at these events. These intellectual people are not attending the events that only the Turkish people organize. We also have a friend in the parliament, from the Greens. She is Alev Korun from the Greens. She was a friend of ours, we know her and she is one of us.

Being successful in intellectual professions is clearly more valued than mere material success. The participants are proud to belong to a social circle comprised of people who are either experts in their fields or artists and intellectuals. In this way, they also distance themselves from both low-skilled workers and rich individuals who lack cultural capital.

The following table shows the internal cultural boundaries set by the choirs' members in a Durkheimian sense. The profane characteristics are associated with listeners of Arabesk.

Table 2: Sacred and profane in the Turkish diaspora

\begin{tabular}{|l|l|}
\hline SACRED & PROFANE \\
\hline Urban values & Rural values \\
\hline Association with the culture of large cities & Association with the culture of Anatolia \\
\hline Secular, educated citizens & Bigoted, uncultivated, impure masses \\
\hline Intellectual elite, professional success & Kiro, maganda \\
\hline
\end{tabular}

I have not observed a clear distinction between moral and cultural boundaries in Lamont's sense when they are drawn on the basis of music. Rather, moral, cultural, and socioeconomic boundaries are intermingled. To be more precise, moral judgments are made on the basis of perceived of cultural differences and cultural superiority. Even seemingly economic boundaries derive from cultural differences and are expressed in moral terms. Hence, the boundary work revolving around music is absolute and not confined to cultural boundaries. On the contrary, when the boundaries are drawn around other issues, they are not necessarily merged. For instance, the symbolic boundaries some participants draw against the religious minority Alevis are solely moral, without involvement of cultural and socioeconomic boundaries. This shows the significance of music as a resource for boundary drawing. 


\section{Discussion}

Eviatar Zerubavel (1997: 53-57) argues that society has an impact on what occurs in the "minds" of people. Moreover, society has an impact on how people "classify the world". For him, people engage in classification because they are "social beings". He stresses that people do not classify because they are "individuals" or "human beings". Zerubavel defines three types of mindsets: "rigid", "flexible", and "fuzzy". The rigid-minded individual is defined as "highly inflexible", a "purist" who functions according to "either/or" reasoning. "Flexible-mindedness" is defined as a "fluid mindset" that recognizes the existence of "both/ and" and promotes "ambiguity". Zerubavel associates fuzzy-mindedness with "an aversion to any boundary that might prevent mental interpenetration".

My findings indicate that the participants tend to communicate in a rigid-minded manner when discussing other Turks in Germany. The differences are in that case put forward as dichotomous binaries of sacred and profane. However, when contrasting the Turkish and German domains, flexible-mindedness is much more prevalent. The German sphere is not regarded as profane, but rather as differently sacred. Although some participants argue that Turkish Art and Folk music is more valuable than German mainstream music, music is not a cultural resource used to draw impermeable boundaries between the participants and Germans. No genre of German music is othered in the way that the Arabesk is. German classical music is widely respected, and German pop is not taken as a symbol of otherness. Even if they do not like something German and do not associate themselves with it, they do not ascribe to it such negative values and attributes as in the case of the Turkish "profane". The differences exemplified in sacred and differently sacred are not binary opposites, but frequently they are even taken as complementary qualities. Such as the contrasting of Turkish Classical music and Western Classical Music, the "warm-bloodedness" of Turks with the "cool-headedness" of Germans, Turkish friendliness with German discipline and rule of law, emotion with rationality, and Turkish etiquette with German etiquette.

In future researches, this argument of creating differentiation within the diaspora on the basis of music can be studied in other cases, such as with Serbians. The majority of Serbs in Germany came in the same wave with Turkish guest workers. Nonetheless, as a result of the massive brain drain from Serbia in the 1990s that followed the dissolution of Yugoslavia, the earlier migrants were joined by a high number of highlyskilled professionals. In the Serbian case, there is a tension between listeners of the hybrid music genre of Turbo Folk and Western music. Turbo Folk is comparable to Arabesk and many songs describe homesickness and suffering in a foreign land.

But Turbo Folk has never been popular among pro-Western, educated Serbian elites. As in the Turkish Arabesk case, it is a genre associated with the backwardness and the Orient. According to Marina Simic, "'turbo folk' music was connected to the concepts of 'Balkanness', 'rurality' and 'barbarity"' (Simic 2010: 327). Although it emerged at the end of the $20^{\text {th }}$ century, its origins are frequently found in the role of the Ottoman Empire's hegemony over Serbia. Furthermore, according to Simic, for young, well-educated Serbs who listen to Western music and identify with it, "identification strategies were directed towards 'cosmopolitan' practices that exceeded local boundaries" (Ibid.: 326). 


\section{References}

ALEXANDER, Jeffrey C. 1990. "Analytic Debates: Understanding the Relative Autonomy of Culture." Pp. 1-30 in Culture and Society: Contemporary Debates, edited by Jeffrey C. ALEXANDER and Steven SEIDMAN. Cambridge: Cambridge University Press.

ALEXANDER, Jeffrey C. 2003. "The Sacred and Profane Information Machine." Pp. 179-192 in The Meanings of Social Life: A Cultural Sociology by Jeffrey C. ALEXANDER. Oxford: Oxford University Press.

ALEXANDER, Jeffrey C. and Philip SMITH. 2003. "The Strong Program in Cultural Sociology: Elements of a Structural Hermeneutics." Pp. 11-26 in The Meanings of Social Life: A Cultural Sociology by Jeffrey C. ALEXANDER. Oxford: Oxford University Press.

BARTMANSKI, Dominik and Jeffrey C. ALEXANDER. 2012. "Introduction: Materiality and Meaning in Social Life: Toward an Iconic Turn in Cultural Sociology.” Pp. 1-12 in Iconic Power: Materiality and Meaning in Social Life, edited by Jeffrey C. ALEXANDER, Dominik BARTMANSKI and Bernhard GIESEN. New York: Palgrave Macmillan.

BAUMAN, Zygmunt. 1987. Legislators and Interpreters: On Modernity, Post-Modernity and Intellectuals. Cambridge: Polity Press.

BERGHAHN, Daniela. 2011. “'Seeing Everything with Different Eyes': The Diasporic Optic in Fatih Akin's Head-On (2004).” Pp. 235-252 in New Directions in German Cinema, edited by Paul COOKE and Chris HOMEWOOD. London: I.B. Tauris.

BENNETT, Andy. 2015. "Identity: Music, Community, and Self." Pp. 143-151 in The Routledge Reader on the Sociology of Music, edited by John SHEPHERD and Kyle DEVINE. New York: Routledge.

BOHNSACK, Ralf and Arnd-Michael NOHL. 2003. "Youth Culture as Practical Innovation: TurkishGerman Youth, Time Out and the Actionisms of Breakdance.” European Journal of Cultural Studies 6(3): 366-385.

BOHNSACK, Ralf. 2010. "Documentary Method and Group Discussion." Pp. 99-124 in Qualitative Analysis and Documentary Method, edited by Ralf BOHNSACK, Nicolle PFAFF and Wivian WELLER. Leverkusen Opladen: Barbara Budrich Publishers.

BOURDIEU, Pierre. 2010. Distinction: A Social Critique of the Judgement of Taste. New York: Routledge.

CHARMAZ, Kathy. 2006. Constructing Grounded Theory: A Practical Guide through Qualitative Analysis. London: SAGE.

DEMIRALP, Seda. 2012. "White Turks, Black Turks? Faultlines Beyond Islamism versus Secularism." Third World Quarterly 33(3): 511-524.

DOUGLAS, Mary. 1966. Purity and Danger: An Analysis of the Concepts of Pollution and Taboo. London: Routledge.

GEERTZ, Clifford. 1973. The Interpretation of Cultures: Selected Essays. New York: Basic Books.

HAMMERSLEY, Martyn and Paul ATKINSON. 2007. Ethnography: Principles in Practice. New York: Routledge.

KIRIKKANAT, Mine. 2005. "Halkımız Eğleniyor." [Our People are Having Fun]. July 27. Radikal.

KÜÇÜKKAPLAN, Uğur. 2013. Arabesk: Toplumsal ve Müziksel Bir Analiz [Arabesk: A Social and a Musical Analysis]. Istanbul: Ayrıntı Yayınları.

LAMONT, Michele. 1992. Money, Morals, and Manners: The Culture of the French and American Upper-Middle Class. Chicago: University of Chicago Press.

ÖNCÜ, Ayşe. 1999. "Istanbulites and Others: The Cultural Cosmology of 'Middleness' in the Era of NeoLiberalism.” Pp. 95-119 in Istanbul between the Global and the Local, edited by Çağlar KEYDER. New York: St. Martins.

ÖZBEK, Meral. 1991. Popüler Kültür ve Orhan Gencebay Arabeski [Popular Culture and the Arabesk of Orhan Gencebay]. Istanbul: İletişim. 
SIMIC, Marina. 2010. "Locating Cosmopolitanism: Practicing Popular Culture in Post-Socialist Serbia." Der Donauraum 50 (3-4): 325-343.

SPILLMAN, Lyn. 2002. "Introduction: Culture and Cultural Sociology." Pp 1-15 in Cultural Sociology, edited by Lyn SPILLMAN. Oxford: Blackwell Publishers.

STOKES, Martin. 1992. The Arabesk Debate: Music and Musicians in Modern Turkey. Oxford: Oxford University Press.

STOKES, Martin. 1994. "Introduction: Ethnicity, Identity, and Music.” Pp. 1-27 in Ethnicity, Identity, and Music: The Musical Construction of Place, edited by Martin STOKES. Oxford: Berg.

STOKES, Martin. 2000. "East, West, and Arabesk." Pp. 213-233 in Western Music and Its Others: Difference, Representation and Appropriation in Music, edited by Georgina BORN and David HESMONDHALGH. Berkeley: University of California Press.

ZERUBAVEL, Eviatar. 1997. Social Mindscapes: An Invitation to Cognitive Sociology. Cambridge, MA: Harvard University Press.

\section{Author}

Ali Türünz received his Ph.D. degree from the Department of Sociology in Masaryk University in 2016. His dissertation was titled „Music as a Resource in the Migratory Context: Turkish Choirs in Hamburg“. His research interests are cultural sociology, sociology of music, transnational migration and social movements.

Contact: 191542@mail.muni.cz 